\title{
Use of erythromycin as a means of preventing vertical transmission of Renibacterium salmoninarum
}

\author{
T. P. T. Evelyn, J. E. Ketcheson \& L. Prosperi-Porta \\ Department of Fisheries and Oceans, Fisheries Research Branch, Pacific Biological Station, Nanaimo, British Columbia \\ V9R 5K6, Canada
}

\begin{abstract}
The salmonid pathogen Renibacterium salmoninarum is now known to be transmitted from parent to progeny within the salmonid egg. Two groups of experiments were conducted to evaluate the possible efficacy of the antibiotic erythromycin in preventing this mode of $R$. salmoninarum transmission. The first evaluated the widely practised disinfection technique of waterhardening eggs in aqueous erythromycin. Eggs treated in this manner rapidly accumulated the antibiotic, but only in the perivitelline fluid, not in the yolk where the intra-ovum pathogen is thought to occur. Further, the erythromycin was leached from the egg too rapidly to permit any bactericidal activity. The second group of experiments investigated erythromycin levels attained in eggs when the broodfish were injected with the antibiotic prior to spawning. Fish injected with erythromycin (20 $\mathrm{mg}$ antibiotic [ $\mathrm{kg} \mathrm{fish}]^{-1}$ ) 30 to $56 \mathrm{~d}$ prior to spawning yielded eggs containing levels of the antibiotic that exceeded the minimum lethal concentration determined for $R$. salmoninarum. Moreover, the drug was not leachable and it occurred in the yolk where it would contact the intra-ovum pathogen. We failed in an attempt to infect antibiotic-containing eggs from erythromycin-injected fish using $R$. salmoninarum and an in vitro infection method always previously successful with antibiotic-free eggs. This encouraging result indicates that further studies to evaluate the broodstock injection procedure are clearly warranted.
\end{abstract}

\section{INTRODUCTION}

Bacterial kidney disease (BKD) is a systemic infection of salmonids that is normally chronic and usually fatal. The disease is considered important because of the serious losses it causes and because of the difficulty with which it is controlled. As indicated in 2 recent reviews (Fryer \& Sanders 1981, Klontz 1983), prevention of BKD by vaccination is not yet feasible, and control by chemotherapy has met with only limited success. Control of BKD is therefore best accomplished by avoiding the responsible bacterium, Renibacterium salmoninarum.

It has long been known that the pathogen is spread horizontally, but suspicions that it might also be transmitted vertically, via the salmonid egg, have only been corroborated relatively recently (Bullock et al. 1978). Since this finding, it has been shown that bathing eggs in povidone-iodine to free them of the pathogen is ineffective because the pathogen occurs within the salmonid egg, out of reach of the disinfectant (Evelyn et al. 1984a, b; 1986a)

Evidence incriminating the egg in the spread of BKD prompted studies with erythromycin to determine whether the disease could be prevented by breaking the infection cycle at the egg stage. Erythromycin has long been considered the antibiotic of choice for combatting Renibacterium salmoninarum infections (Wolf \& Dunbar 1959) - a view that appears to have been supported by recent results (Austin 1985). Unfortunately, the literature dealing with erythromycin as an 'egg disinfectant' is both contradictory and ambiguous. For example, Klontz (1983) reported that the widely practised technique of water-hardening eggs in aqueous erythromycin was effective at preventing the vertical transmission of $R$. salmoninarum. This report has, however, not been supported by the work of others (Groman 1983, Evelyn et al. 1986b). Klontz (1983) also reported that the progeny of $R$. salmoninarum-infected broodstock suffered less severe BKD when the brood- 
stock was injected with erythromycin prior to spawning. This promising finding may be due to the fact that the eggs of injected broodfish accumulate therapeutic levels of erythromycin under certain circumstances (Groman 1983, Bullock \& Leek 1986). However, the reports on the broodstock injection procedure are ambiguous with regard to the circumstances under which these intra-ovum levels of the antibiotic accumulate, and are contradictory with respect to the persistence of the antibiotic in the eggs. The present study was undertaken in an attempt to answer some of the questions raised in the literature concerning erythromycin as an 'egg disinfectant'.

\section{MATERIALS AND METHODS}

Two groups of experiments were conducted. The first examined the fate of erythromycin administered to eggs during water-hardening. The second investigated the erythromycin levels attained in eggs when broodfish were injected with the antibiotic at various times prior to spawning.

Eggs, milt, and fish. Fish serving as the source of eggs and milt in these experiments were all healthy-appearing adults that had returned from the sea to spawn. Eggs and milt used in the first group of experiments were obtained from ripe coho and chinook salmon (Oncorhynchus kisutch and O. tshawytscha, respectively) and from ripe steelhead trout (Salmo gairdneri) at the Department of Fisheries and Oceans' (DFO) fish culture facilities at Big Qualicum River (the salmon) and Rosewall Creek (the trout), Vancouver Island, British Columbia (B. C.), Canada. In the second group of experiments, the eggs were obtained from erythromycin-injected coho salmon at DFO fish culture facilities at Quinsam River, Vancouver Island, B. C. and at Capilano River near Vancouver, B. C. The brood coho had been injected one or more times prior to spawning (see Table 2) with erythromycin in the form of Gallimycin 200 (APA Inc., Calgary, Alberta, Canada), the dosage being equivalent to $20 \mathrm{mg}$ of erythromycin base per $\mathrm{kg}$ fish per injection. The injections were administered between the epaxial muscles, just anterior to the dorsal fin, and were part of a cooperative study between the fish culture facility staff and DFO Diagnostic Service staff aimed at preventing prespawning mortalities in early-returning broodstock.

Eggs and milt samples were returned to the laboratory, separately, in clean, covered, iced, plastic containers and stored at 0 to $4{ }^{\circ} \mathrm{C}$ until used. Care was taken to ensure that the samples had access to oxygen.

Egg handling protocols. Eggs in both experiments were either 'dry-fertilized' (Evelyn et al. 1986b) or left unfertilized. In the first group of experiments, the erythromycin was infused into the eggs by water-hardening them without stirring for 1 or more hours at 4 or $10^{\circ} \mathrm{C}$ in one egg volume of water containing one of several forms of erythromycin equivalent to 10 or $50 \mu \mathrm{g}$ of erythromycin base per ml. (Details of the treatments applied to the various lots of eggs are given in Table 1). The various forms of erythromycin tested were: erythromycin phosphate, erythromycin base, erythromycin estolate, erythromycin ethylsuccinate, and erythromycin stearate. Sources of these antibiotics were as indicated in Evelyn et al. (1986b). The egg contents were sampled either immediately after water-hardening, or after subjecting the eggs to leaching by incubating them for 1 or $7 \mathrm{~d}$ in antibiotic-free running water (total hardness: $18 \mathrm{ppm}$ as $\mathrm{CaCO}_{3} ; 6$ to $9^{\circ} \mathrm{C}$ ). The samples consisted of the entire egg contents and were removed with a 26 gauge needle fitted to a $1 \mathrm{ml}$ syringe. Pror to sampling, the eggs were given a quick rinse with distilled water and were dried using clean blotting paper.

In the second group of experiments the eggs were sampled, soft and unfertilized, immediately following their removal from the antibiotic-injected fish, or after insemination, hardening in antibiotic-free water, and leaching in running water for various periods ( 7 to 77 d). For sampling, the eggs were blotted free of coelomic fluid or water, and their contents were then collected as outlined above.

In both groups of experiments, controls consisted of egg content samples derived from eggs that had never been exposed to erythromycin.

Erythromycin assay. The concentration of erythromycin present in the egg content samples was determined microbiologically using a strain of Sarcina lutea capable of detecting amounts of erythromycin as low as $0.0025 \mu \mathrm{g} 10 \mu \mathrm{l}^{-1}$ sample. The assay was a modification of the cylinder plate method (Difco Supplementary Literature, 1968 p. 12-13). Briefly, 10ul samples of the egg contents or of standard erythromycin solutions $\left(0.25\right.$ to $\left.4.0 \mu \mathrm{g} \mathrm{mi}^{-1}\right)$ were applied to dry, sterile, blotting paper discs ( $7 \mathrm{~mm}$ diameter) and the latter were placed on the surface of a heavily seeded antibiotic assay medium (medium 11, Difco Laboratories, Detroit, Michigan, USA) in standard plastic Petri plates. The plates were prepared by pouring a base layer of $20 \mathrm{ml}$ of medium and overlaying it with $6 \mathrm{ml}$ of the same medium seeded with $0.1 \mathrm{ml}$ of a phosphatebuffered saline suspension of the assay organism (1.0 O.D at $540 \mathrm{~nm} ; \mathrm{pH} 7.2$ ). The plates were incubated right-side-up, for 2 or $3 \mathrm{~d}$ at 21 to $22{ }^{\circ} \mathrm{C}$ and the amounts of antibiotic in the egg samples were determined by comparing the diameters of the zones of growth inhibition they produced with a standard curve based on zones of inhibition obtained with known amounts of erythromycin. 


\section{RESULTS AND DISCUSSION}

The results in Table 1 indicate that eggs of all 3 species of salmonids tested imbibed erythromycin when hardened in aqueous solutions of the antibiotic. Similar results were obtained with eggs of chinook salmon by Groman (1983) and Bullock \& Leek (1986). No systematic attempt was made to investigate the effects of varying the time of exposure, temperature, and antibiotic concentration on the amount of erythromycin taken up by the eggs. It is clear, however, that even that combination of time $(1 \mathrm{~h})$, temperature $\left(4^{\circ} \mathrm{C}\right)$, and antibiotic concentration $\left(10 \mu \mathrm{g} \mathrm{ml}^{-1}\right)$ least likely to result in maximum erythromycin uptake yielded intraovum levels of the antibiotic $\left(1.4\right.$ and $1.7 \mu \mathrm{g} \mathrm{ml}^{-1}$ in coho salmon no. 1 and steelhead trout no. 1 eggs, respectively) that exceeded the minimum lethal concentration (MLC) found for Renibacterium salmoninarum ( $\mathrm{MLC}=<0.3 \mu \mathrm{g}$ erythromycin base $\mathrm{ml}^{-1}$ ). The MLC was determined by exposing $R$. salmoninarum cells, suspended at 100 cells ml-1 in the broth form of KDM2 (Evelyn 1977), to the antibiotic for $7 \mathrm{~d}$ at $10^{\circ} \mathrm{C}$ and then testing the cells for their viability in the absence of the antibiotic.

On the basis of the foregoing, it may be difficult to see why eggs water-hardened in erythromycin should not have been freed of intra-ovum Renibacterium salmoninarum. However, as shown in Table 1, the imbibed antibiotic is not retained in the egg. Even forms of erythromycin such as erythromycin stearate, not readily soluble in water, were leached from the eggs once the eggs were incubated in running antibiotic-free water. (In contrast, eggs incubated in moist air for 1 or more days retained the antibiotic; unpubl. data.) Tests with steelhead eggs revealed that the loss of antibiotic due to leaching was very rapid: erythromycin levels fell from $1.7 \mu \mathrm{g} \mathrm{ml}^{-1}$ to $0.9 \mu \mathrm{g} \mathrm{ml} l^{-1}$ within $20 \mathrm{~min}$ - a loss of almost $50 \%$. The rapid leaching of the antibiotic from the eggs has also been reported by others (Groman 1983, Bullock \& Leek 1986) and may serve to explain why water-hardening eggs in erythromycin proved ineffective in eliminating the intra-ovum pathogen. Considering the low water temperatures under which salmonid eggs are normally incubated, the pathogen is not likely to be very active metabolically. Under these conditions, the pathogen would show reduced susceptibility to the antibiotic, and long contact times, made impossible due to leaching, would likely be required to ensure the effectiveness of the procedure.

A second and equally valid explanation for the lack of efficacy of the egg disinfection procedure involves the distribution of the erythromycin within the egg. The rapid leaching of the antibiotic from the egg strongly suggests that the antibiotic occurs in the perivitelline fluid compartment rather than in the yolk because perivitelline fluid is the only fluid in the salmonid egg that is in rapid equilibrium with the water surrounding the egg (Potts \& Rudy 1969, Rudy \& Potts 1969). In this location, the antibiotic would probably not come in contact with the pathogen because the latter apparently occurs in the yolk (Evelyn et al.

Table 1. Uptake of erythromycin by eggs during water-hardening and the loss of the antibiotic by leaching in water

\begin{tabular}{|c|c|c|c|c|c|}
\hline Egg source & $\begin{array}{c}\text { Eggs } \\
\text { fertilized }\end{array}$ & $\begin{array}{l}\text { Treatment of } \\
\text { soft eggs }\end{array}$ & $\begin{array}{l}\text { No. eggs } \\
\text { tested }\end{array}$ & $\begin{array}{c}\text { Antibiotic } \\
\text { concentration } \\
\text { attained in eggs } \\
\left(\mu \mathrm{g} \mathrm{ml}^{-1}\right)^{\mathrm{b}}\end{array}$ & $\begin{array}{c}\text { Antibiotic } \\
\text { concentration } \\
\text { in eggs on } \\
\text { leaching }\end{array}$ \\
\hline Steelhead no. 1 & + & $\mathrm{EP}\left(10 \mu \mathrm{g} \mathrm{ml}^{-1} ; 1 \mathrm{~h}_{i} 4^{\circ} \mathrm{C}\right)$ & 10 (pooled) & 1.7 & 0 (10 eggs; pooled) \\
\hline \multirow[t]{5}{*}{ Steelhead no. 2} & + & $\mathrm{EP}\left(50 \mu \mathrm{g} \mathrm{ml}^{-1} ; 2 \mathrm{~h}_{1} 10^{\circ} \mathrm{C}\right)$ & 10 (pooled) & $>4.0$ & 0 (10 eggs; pooled $)$ \\
\hline & & $\mathrm{EB}\left(50 \mu \mathrm{g} \mathrm{ml}^{-1} ; 2 \mathrm{~h} ; 10^{\circ} \mathrm{C}\right)$ & 10 (pooled) & $>4.0$ & $O(10$ eggs; pooled $)$ \\
\hline & & $\mathrm{EE}\left(50 \mu \mathrm{g} \mathrm{ml}^{-1} ; 2 \mathrm{~h} ; 10^{\circ} \mathrm{C}\right)$ & 10 (pooled) & $>4.0$ & O (10 eggs; pooled $)$ \\
\hline & & $\operatorname{EES}\left(50 \mu \mathrm{g} \mathrm{ml}^{-1} ; 2 \mathrm{~h} ; 10^{\circ} \mathrm{C}\right)$ & 10 (pooled) & $>4.0$ & O (10 eggs; pooled) \\
\hline & & $\mathrm{ES}\left(50 \mu \mathrm{g} \mathrm{ml}^{-1} ; 2 \mathrm{~h} ; 10^{\circ} \mathrm{C}\right)$ & 10 (pooled) & $>4.0$ & 0 (10 eggs; pooled $)$ \\
\hline Steelhead no. 3 & + & $\mathrm{EP}\left(50 \mu \mathrm{g} \mathrm{ml}^{-1} ; 17 \mathrm{~h} ; 4{ }^{\circ} \mathrm{C}\right)$ & 10 (individually) & $1.4-3.8$ & 0 (10 eggs; individually) \\
\hline Coho no. 1 & + & $\mathrm{EP}\left(10 \mu \mathrm{g} \mathrm{ml}^{-1} ; 1 \mathrm{~h}_{2} 4^{\circ} \mathrm{C}\right)$ & 10 (pooled) & 1.4 & 0 (10 eggs; pooled $)$ \\
\hline Coho no. 2 & + & $\mathrm{EP}\left(50 \mu \mathrm{g} \mathrm{ml}^{-1} ; 24 \mathrm{~h} ; 4^{\circ} \mathrm{C}\right)$ & 5 (individually) & $2.0->4.0$ & NT \\
\hline Chinook no. 1 & - & $\mathrm{EP}\left(50 \mu \mathrm{g} \mathrm{ml} \mathrm{m}^{-1} ; 2 \mathrm{~h} 4^{\circ} \mathrm{C}\right)$ & 10 (individually) & $2.1-3.2$ & NT \\
\hline \multicolumn{6}{|c|}{$\begin{array}{l}{ }^{a} \text { Eggs were incubated without stirring in one egg volume of aqueous antibiotic }\left(10 \text { or } 50 \mu \mathrm{g} \mathrm{ml}^{-1}\right) \text { for indicated times and at } \\
\text { indicated ternperatures. EP: erythromycin phosphate; EB: erythromycin base; EE: erythromycin estolate; EES: erythromycin } \\
\text { ethylsuccinate; ES: erythromycin stearate } \\
\text { f Antibiotic concentrations found for total egg contents; the contents of control eggs, hardened in water only, were antibiotic- } \\
\text { free } \\
{ }^{c} \text { Eggs were leached in flowing antibiotic-free water for } 1 \mathrm{~d} \text { (steelhead no. } 2 \text { ) or } 7 \mathrm{~d} \text { (all other fish) } \\
\text { NT: not tested }\end{array}$} \\
\hline
\end{tabular}


1984a, 1986a). Additional information, obtained with chinook salmon eggs, suggests that erythromycin, administered to the eggs during water-hardening, occurs only in the perivitelline fluid. The perivitelline fluid was not sampled directly to prove this point because it seemed an impossibly small target to sample cleanly. Instead, attempts were made to obtain 'yolk only' samples from treated eggs that had been established as containing erythromycin. If 'yolk only' samples from these eggs proved negative for erythromycin, this would indicate that the antibiotic was present in the perivitelline fluid. The actual findings follow. Ten out of 10 chinook salmon eggs, treated by water-hardening in aqueous erythromycin $\left(50 \mu \mathrm{g} \mathrm{ml}^{-1}\right)$ at $4{ }^{\circ} \mathrm{C}$ for $2 \mathrm{~h}$, were shown to contain erythromycin (2.1 to $3.2 \mu \mathrm{g} \mathrm{ml}^{-1}$ ) when the samples tested consisted of total egg contents (i. e. yolk and perivitelline fluid) (Table 1). In contrast, 'yolk only' samples from 37 eggs drawn from this same batch of eggs yielded erratic results: 21 were devoid of erythromycin while 16 contained detectable erythromycin $\left(0.1\right.$ to $\left.2.4 \mu \mathrm{g} \mathrm{ml} \mathrm{m}^{-1}\right)$ (data not shown in Table 1). The most reasonable interpretation of these findings is that the antibiotic occurred in the perivitelline fluid, not the yolk, but that it was not always possible to obtain yolk samples without contaminating them with the surrounding antibiotic-laden perivitelline fluid.

At the moment, a more promising procedure for treating eggs to free them of intra-ovum Renibacterium salmoninarum is an indirect one that involves injecting the females with erythromycin prior to spawning. The data in Table 2 indicate that fish injected 30 to $56 \mathrm{~d}$ prior to spawning (but not earlier) yielded eggs containing erythromycin at levels that exceeded the MLC found for $R$. salmoninarum. Groman (1983) and Bullock
\& Leek (1986) also reported the accumulation of erythromycin in the eggs of erythromycin-injected broodfish but the timing of the injections was not specified even though it appeared that there was an awareness that this might be critical. In the present experiment, the virtually complete lack of antibiotic in the eggs of broodfish injected at 70 or $90 \mathrm{~d}$ prior to spawning underlines the importance of timing the injections correctly. Explanations for the lack of antibiotic in the eggs of fish injected at this stage can only be speculated on: it may reflect the increased opportunity for clearance of the antibiotic from the eggs or a lack of active antibiotic uptake by the eggs at this stage.

The erythromycin found in eggs obtained from fish injected at 30 to $56 \mathrm{~d}$ before spawning must have been present in the yolk because it occurred in sofi eggs which lack perivitelline fluid (Table 2). In the yolk, antibiotic-pathogen contact would likely be inevitable. Further, in agreement with Bullock \& Leek (1986) but in disagreement with Groman (1983), the antibiotic persisted in the egg despite attempts to leach it away (Table 2). Prolonged contact with the intra-ovum pathogen would therefore be possible, thus increasing the chances for its successful elimination.

The non-leachable property of the antibiotic in the eggs from injected broodfish should be particularly important with Renibacterium salmoninarum because this pathogen is thought normally to infect mature eggs, just prior to spawning (Evelyn et al. 1986b). Natural $R$. salmoninarum infections of immature eggs should, of course, also be effectively treated using the broodfish injection technique. However, if such infections occur, they must be rare because they have not yet been reported. Bruno \& Munro (1986) have shown, experimentally, that immature eggs can be infected,

Table 2. Erythromycin content of eggs derived from coho salmon injected at various times prespawning with erythromycin phosphate. Dosage was equivalent to $20 \mathrm{mg}$ erythromycin base $(\mathrm{kg} \mathrm{fish})^{-1}$ injection $^{-1}$

\begin{tabular}{|c|c|c|c|c|}
\hline $\begin{array}{l}\text { No. of injections } \\
\text { per fish }\end{array}$ & $\begin{array}{l}\text { Timing of injection(s) } \\
\text { (no. of d prespawning) }\end{array}$ & $\begin{array}{l}\text { Sample: individual or } \\
\text { pooled egg contents }\end{array}$ & $\begin{array}{l}\text { Erythromycin }\left(\mu \mathrm{g} \mathrm{ml}^{-1}\right) \\
\text { in egg contents }\end{array}$ & $\begin{array}{c}\text { Erythromycin }\left(\mu \mathrm{g} \mathrm{ml}^{-1}\right) \\
\text { in eggs on leaching }\end{array}$ \\
\hline 1 & 30 & Individual (Fish no. 1) & $0.50-1.00$ & $0.50-0.77(7)$ \\
\hline 1 & 30 & Individual (Fish no. 2) & $0.60-0.70$ & $0.58-1.16(18)$ \\
\hline 1 & 70 & Individual (Fish no. 3) & 0 -trace & NT \\
\hline 1 & 70 & Individual (Fish no. 4) & 0 -trace & NT \\
\hline 1 & 90 & Pooled (Fish no. 5) & 0 & NT \\
\hline 2 & 97,56 & Individual (Fish no. 6) & $0.74-0.92$ & NT \\
\hline 2 & 97,56 & Individual (Fish no. 7 ) & $0.66-1.00$ & $0.66-0.92(7)$ \\
\hline 3 & $123,84,34$ & Pooled (Fish no. 8) & $0.32-0.42$ & $0.38(77)$ \\
\hline \multicolumn{5}{|c|}{$\begin{array}{l}{ }^{\text {a }} \text { Contents of } 10 \text { eggs were examined individually or after pooling } \\
\text { b These samples were from soft, unfertilized eggs. Egg content samples from fish not injected with erythromycin were } \\
\text { antibiotic-free } \\
{ }^{c} \text { Leaching was conducted in antibiotic-free running water }\left(6 \text { to } 9^{\circ} \mathrm{C}\right) \text { for the number of days indicated in parentheses; these } \\
\text { eggs were fertilized } \\
\text { NT: not tested }\end{array}$} \\
\hline
\end{tabular}


but the level of $R$. salmoninarum challenge used to effect the infections was so severe that it is doubtful whether the infected eggs or the fish bearing them would have survived to transmit the pathogen vertically. The significance of Bruno \& Munro's finding will therefore require further evaluation.

Positive features of the broodstock injection procedure are the yolk location and non-leachable characteristics of the antibiotic. Negative features of the procedure include the need to have access to fish at a specific period prior to spawning, and the increased risk of generating antibiotic-resistant forms of Renibacterium salmoniarum associated with injecting fish that may be carrying large numbers of the pathogen. That the pathogen can develop resistance to erythromycin has now been firmly established (G. R. Bell unpubl. data).

The technique must be evaluated further to determine whether higher levels of erythromycin are attainable in the eggs, to investigate whether injections closer to spawning time also result in acceptable intraovum concentrations of the antibiotic, and, most important, to assess whether intra-ovum infections with Renibacterium salmoninarum are effectively eliminated. The procedure shows promise, however, because it can be expected to reduce the number of viable $R$. salmoninarum cells in the female, thus reducing the chances that the eggs, and thence the progeny, will become infected. In addition, using antibioticloaded eggs from treated fish, we have for the first time failed to infect eggs using a procedure that has been uniformly successful in infecting antibiotic-free eggs. The egg infection procedure has been described elsewhere (Evelyn et al. 1986b) and mimics the route by which eggs are thought to acquire their infections in the fish.

Acknowledgements. We thank D. Kieser and C. Westby of the DFO Diagnostic Service for providing us with samples of eggs from erythromycin-injected fish and Drs. L. Margolis and G. R. Bell for kindly reviewing the manuscript.

\section{LITERATURE CITED}

Austin, B. (1985). Evaluation of antimicrobial compounds for the control of bacterial kidney disease in rainbow trout, Salmo gairdneri Richardson. J. Fish Dis. 8: 209-220
Bruno, D. W., Munro, A. L. S. (1986). Observations on Renibacterium salmoninarum and the salmonid egg. Dis. aquat. Org. 1: 83-87

Bullock, G. L., Leek, S. L. (1986). Use of erythromycin in reducing vertical transmission of bacterial kidney disease Vet. Hum. Toxicol. 28 (Suppl. 1): 18-20

Bullock, G. L., Stuckey, H. M., Mulcahy, D. (1978). Corynebacterial kidney disease: egg transmission following jodophore disinfection. Fish Health News 7: 51-52

Difco Supplementary Literature (1968). Difco Laboratories. Detroit, Michigan

Evelyn, T. P. T. (1977). An improved growth medium for the kidney disease bacterium and some notes on using the medium. Bull. off. Int. Epiz. 87: 511-513

Evelyn, T P. T., Ketcheson, J. E., Prosperi-Porta, L. (1984a). Further evidence for the presence of Renibacterium salmoninarum in salmonid eggs and for the failure of povidone-iodine to reduce the intra-ovum infection rate in water-hardened eggs. J. Fish Dis. 7: 173-182

Evelyn, T. P. T., Prosperi-Porta, L., Ketcheson, J. E. (1984b). The salmonid egg as a vector of the kidney disease bacterium, Renibacterium salmoninarum. In: ACUIGRUP (ed.) Fish diseases, 4th COPRAQ session. EDITORA ATP, Madrid, Spain, p. 111-117

Evelyn, T. P. T., Prosperi-Porta, L., Ketcheson, J. E. (1986a). Persistence of the kidney disease bacterium, Renibacterium salmoninarum, in coho salmon, Oncorhynchus kisutch (Walbaum), eggs treated during and after waterhardening with povidone-iodine. J. Fish Dis. (in press)

Evelyn, T. P. T., Prosperi-Porta, L., Ketcheson, J. E. (1986b). Experimental intra-ovum infection of salmonid eggs with Renibacterium salmoninarum and vertical transmission of the pathogen with such eggs despite their treatment with erythromycin. Dis. aquat. Org. 1: 197-202

Fryer, J. L., Sanders, J. E. (1981). Bacterial kidney disease of salmonid fish. Ann. Rev. Microbiol. 35: 273-298

Groman, D. B. (1983). Studies examining the identification, epizootiology, and control of Renibacterium salmoninarum infections in chinook salmon (Oncorhynchus tshawytscha). Ph. D. dissertation, University of Idaho, Moscow, Idaho

Klontz, G. W. (1983). Bacterial kidney disease in salmonids: An overview. In: Anderson, D. P., Dorson, M., Dubourget, P. H. (ed.). Antigens of fish pathogens. Collection Fondation Marcel Merieux, p. 177-199

Potts, W. T. W., Rudy, Jr., P. P. (1969). Water balance in the eggs of the Atlantic salmon Salmo salar. J. exp. Biol. 50: 223-237

Rudy, Jr., P. P., Potts, W. T. W. (1969). Sodium balance in the eggs of Atlantic salmon, Salmo salar. J. exp. Biol. 50: 239-246

Wolf, K., Dunbar, C. E. (1959). Test of 34 therapeutic agents for control of kidney disease in trout. Trans. Am. Fish. Soc. 88: $117-124$ 